\title{
DETECTION OF FUMONISIN PRODUCING FUSARIUM VERTICILLIOIDES IN PADDY (ORYZA SATIVA L.) USING POLYMERASE CHAIN REACTION (PCR)
}

\author{
P.K. Maheshwar'; S. Ahmed Moharram²; G.R. Janardhana ${ }^{2 *}$ \\ ${ }^{1}$ Department of Microbiology, Yuvaraja's College, University of Mysore, Mysore- 570 005, Karnataka, India; \\ ${ }^{2}$ Department of Studies in Botany, University of Mysore, Manasagangotri, Mysore- 570 006, Karnataka, India.
}

Submitted: December 27, 2007; Returned to authors for corrections: February 13, 2008; Approved: February $25,2009$.

\begin{abstract}
The study reports the occurrence of fumonisin producing Fusarium verticillioides in 90 samples of stored paddy (Oryza sativa L.) collected from different geographical regions of Karnataka, India. Fumonisin producing F. verticillioides was identified based on micromorphological characteristics and PCR using two sets of primers. One set of primers was $F$. verticillioides species specific, which selectively amplified the intergenic space region of rDNA. The other set of primers was specific to fumonisin producing $F$. verticillioides. Eight paddy samples were positive for $F$. verticillioides. Eleven isolates obtained from these samples were capable of producing fumonisin.
\end{abstract}

Key words: Fusarium verticillioides, fumonisin, paddy, PCR

\section{INTRODUCTION}

Mycotoxigenic fungi are natural contaminants of cereals worldwide (9). Mycotoxins are secondary metabolites of fungi, which may contaminate animal and human foods. Grain spoilage reduces the nutritional value of cereals, resulting in 5\% losses of foodstuff in world. Although there are many species of toxigenic moulds, only a few mycotoxins, particularly those affecting cereals, are considered to be significant for humans (26).

Fumonisins are one of the most recently discovered cytotoxic and carcinogenic mycotoxins, mainly produced by Fusarium verticillioides (Sacc.) Nirenberg (previously known as Fusarium moniliforme, Sheldon) (7). To date, 28 structurally related fumonisin analogues have been identified, only three of them fumonisin $\mathrm{B}_{1}\left(\mathrm{FB}_{1}\right), \mathrm{B}_{2}$ and $\mathrm{B}_{3}$ occur abundantly (13). Among different fumonisins isolated and characterized, fumonisin $B_{1}$ is known to cause a unique neurotoxic syndrome called equine leukoencephalomalacia (ELEM) in horse (23). It has been shown that fumonisin $B_{1}$ is hepato carcinogenic to rats and is also associated with pulmonary edema in swine (19). Ingestion of moldy corn, infected by $F$. verticillioides is linked with high incidence of human liver cancer and esophageal cancer, in the regions of South Africa and China (14). The International Agency for Research on Cancer (IARC) evaluated $\mathrm{FB}_{1}$, as possible carcinogen to humans (Group 2B) (10).

In India, paddy (rice) is the staple food for $65 \%$ of the population and is a high calorific cereal grain (2). Despite the elementary importance of paddy, the unfavorable conditions during harvesting and processing, paddy crop is susceptible to fungal infection and subsequent deterioration during storage. Earlier studies revealed the occurrence of many mycotoxigenic fungi including species of Fusarium on paddy (17). Therefore the detection and control of Fusarium species is crucial to prevent toxins entering the food chain.

PCR protocols based on rDNA sequences have been extensively used for the accurate detection of Fusarium species. Ribosomal DNA sequences have been considered stable and occur in multiple copies, possess characteristics that are suitable for the detection of pathogens up to the species level (11). Many Fusarium species including $F$. verticillioides are mainly seed-borne in paddy (12). However, these moulds are less studied and it is not known whether the isolates on paddy have the potential to produce fumonisins. Hence, the present

*Corresponding Author. Mailing address: Department of Studies in Botany, University of Mysore, Manasagangotri, Mysore- 570 006, Karnataka, India. Phone: +91-821-2419763 Fax:+91-821-2419759. E-mail: janardhanaplantclinic@india.com 
investigation was conducted to know the fumonisin producing F. verticillioides occurring on paddy using PCR.

\section{MATERIALS AND METHODS}

\section{Collection of paddy samples}

For isolation of mycotoxigenic fungi 90 different paddy samples intended for human consumption were collected from farmers of various districts of Karnataka, India, during the months of June-2006 to September- 2006. Samples $(0.5 \mathrm{~kg})$ were packed in sterile polythene bags, appropriately labeled. The grain sample was stored in the laboratory at $5^{\circ} \mathrm{C}$ and mycological analysis was started within a week (18).

\section{Media for isolation of Fusarium species}

Isolation of Fusarium species from paddy was done both by standard blotter as well as agar plating methods. Fusarium species were isolated from paddy, by plating on selective medium such as modified malachite green agar (MGA) medium containing $2.5 \mathrm{mg} / \mathrm{lit}$. malachite green oxalate (6) and maintained on modified Czepek dox agar (CZA) and Spezieller Nahrstoffarmer agar media (SNA) (16).

\section{Isolation of Fusarium species}

For mycological studies, samples were subjected to sampling by hand halving method according to International Seed Testing Association (ISTA) (18). 400 paddy grains were surface sterilized, by $1 \%$ sodium hypochlorite for $1 \mathrm{~min}$. and rinsed twice in sterile distilled water for 30 seconds (21). 200 surface sterilized grains were plated (10 per plate) on MGA2.5 medium containing chloramphenicol $(50 \mathrm{mg} / \mathrm{l})$ and the remaining 200 grains were plated ( 25 per plate) equidistantly on moist blotters. The plates were incubated at $26^{\circ} \mathrm{C}$ for $5-6$ days. The developing fungal colonies were counted directly after incubation and species of Fusarium were sub cultured and identified on potato dextrose agar (PDA) medium $(5,16)$.

\section{DNA extraction for PCR}

The genomic DNA was extracted from all the isolates of $F$. verticillioides $(\mathrm{n}=27), F$. proliferatum $(\mathrm{n}=4), F$. anthophilum $(\mathrm{n}=6), F$. graminearum $(\mathrm{n}=4)$ and Alternaria solani $(\mathrm{n}=1)$ (negative control) respectively. Each fungal species was inoculated to $500 \mu \mathrm{l}$ of sterile potato dextrose broth in $2 \mathrm{ml}$ microfuge tubes, aseptically. The microfuge tubes were then incubated for 5 days at $26^{\circ} \mathrm{C}$. Each fungal isolate was subjected to modified DNA extraction method of Zhang et al. (28). Briefly, microfuge tube containing mycelial growth was centrifuged at $5000 \mathrm{rpm}$ (REMI C24 Cooling Centrifuge) for $8 \mathrm{~min}$. and the broth was discarded. The mycelium was resuspended in the cell lysis buffer ( $2 \%$ CTAB, $1.4 \mathrm{M} \mathrm{NaCl}, 20 \mathrm{mM}$ EDTA, $100 \mathrm{mM}$ Tris- $\mathrm{HCl}, \mathrm{pH} 8.0$, pre-heated at $65^{\circ} \mathrm{C}$ ). The microfuge tubes were heated at $65^{\circ} \mathrm{C}$ for $20 \mathrm{~min}$. in a water bath. To these tubes, equal volume of phenol: chloroform (1:1) was added and centrifuged at $3000 \mathrm{rpm}$ for $5 \mathrm{~min}$. The supernatant was transferred to new microfuge tubes and an equal volume of isopropyl alcohol was added. The microfuge tubes were kept at $-20^{\circ} \mathrm{C}$ for 2 hours for precipitation and then centrifuged at $8000 \mathrm{rpm}$ for $8 \mathrm{~min}$. The DNA pellet was dried and resuspended in $20 \mu \mathrm{l}$ of nuclease free water and used directly for PCR analysis.

\section{Primers for PCR}

VERT-1 and VERT-2 set of primers (5'- GTCAGAA TCCATGCCAGAACG -3' and 5'-CACCCGCAGCAAT CCATCAG-3'), was used specifically to detect $F$. verticillioides. Another set of primers, VERTF-1 (5' - GCGGGAATTC AAAAGTGGCC -3') and VERTF-2 (5' - GAGGGCGCGAAA CGGATCGG -3') as described by Patino et al. (22), was used to detect fumonisin producing ability of $F$. verticillioides. The expected amplicons sizes were $800 \mathrm{bp}$ and $400 \mathrm{bp}$ respectively. The primers were purchased from Bangalore Genei, Bangalore (India).

\section{Polymerase chain reaction (PCR)}

The total genomic DNA from $F$. verticillioides $(\mathrm{n}=27), F$. proliferatum $(\mathrm{n}=4), F$. anthophilum $(\mathrm{n}=6), F$. graminearum $(\mathrm{n}=4)$ and Alternaria solani $(\mathrm{n}=1)$ (negative control) was subjected to PCR analysis using an Advanced Primus 25 Thermocycler (Peqlab, Germany). The PCR mixture included 2 $\mu 1$ of genomic DNA, $1 \mu$ l of each primer ( $20 \mathrm{pmol}), 0.5 \mu \mathrm{l}$ of Taq DNA polymerase $(3 \mathrm{U} / \mu 1), 2.5 \mu \mathrm{l}$ of $10 \mathrm{X}$ PCR buffer, $2.5 \mu \mathrm{l}$ of $\mathrm{MgCl} 2$ and $1 \mu \mathrm{l}$ of $2 \mathrm{mM}$ dNTPs and the final volume was made up to $25 \mu \mathrm{l}$ with nuclease free water. The reagents were purchased from Bangalore Genei, Bangalore (India).

The PCR conditions were maintained at $94^{\circ} \mathrm{C}$ for $4 \mathrm{~min}$. for initial denaturation, followed by 35 cycles of denaturation at $94^{\circ} \mathrm{C}$ for $1 \mathrm{~min}$, primer annealing at $60^{\circ} \mathrm{C}$ for $1 \mathrm{~min}$, primer extension at $72^{\circ} \mathrm{C}$ for $1 \mathrm{~min}$. and final extension at $72^{\circ} \mathrm{C}$ for $5 \mathrm{~min}$. Amplified products were analyzed on $1.5 \%$ agarose gel in $1 \mathrm{X}$ TAE buffer (40 mM Tris acetate and $1.0 \mathrm{mM}$ EDTA) and documented with a gel documentation system (UTP-Bio Doc, USA).

\section{RESULTS AND DISCUSSION}

Mycological analysis using standard blotter and agar plate methods yielded 27 isolates of $F$. verticillioides, in 8 out of 90 paddy samples screened. The isolates of $F$. verticillioides showed cultural and micro morphological characters typical for F. verticillioides as described by Booth (5), Leslie and Summerell (16).

This finding is in good agreement with the earlier studies, which reported the $F$. verticillioides from paddy. Taligoola et al. (25) reported $F$. verticillioides at a relatively higher frequency $(12.5 \%)$ on the paddy seeds. Fusarium infection and fumonisin contamination is a major problem in Pakistan and $20 \%$ of the 
seeds were found naturally infected by $F$. verticillioides (4). Desjardins et al. (2000) have reported $2980 \mu \mathrm{g} / \mathrm{g}$ of fumonisin production from rice culture. This indicates that, even $20 \%$ of $F$. verticillioides infection can be a serious problem, as paddy is the staple food for people of Asia.

$F$. verticillioides was the most common fungi and found in $89.3 \%$ of maize samples from south-western Nigeria (3). In Asia, the incidence of Fusarium and fumonisin contamination is highly prevalent. $F$. verticillioides contamination has been reported from Nepal, where both local and improved varieties of paddy are affected by $F$. verticillioides (8).

When genomic DNA of all the 27 isolates of $F$. verticillioides subjected to PCR, the expected $800 \mathrm{bp}$ amplified product specific to VERT-1 and VERT-2 was amplified. Such amplified product was not detected in other Fusarium species tested namely, F. proliferatum $(\mathrm{n}=4)$ and Alternaria solani $(\mathrm{n}=1)$ (Fig. 1) (Table 1).

Further, 11 out of $27 \mathrm{~F}$. verticillioides isolates scored positive for the VERTF-1 and VERTF-2 set of primers and the expected $400 \mathrm{bp}$ amplicon was detected, indicating their potential fumonisin producing ability. No such amplification was detected in other Fusarium species (Fig. 2) (Table 1). Similar work was done in maize by Pamphile and Azevedo, (20) and reported the endophytic $F$. verticillioides by PCR analysis.

Paddy is the most important food crop with more than $90 \%$ of global production occurring in tropical and semi-tropical Asia. In several Asian countries, it provides $50-70 \%$ of the energy

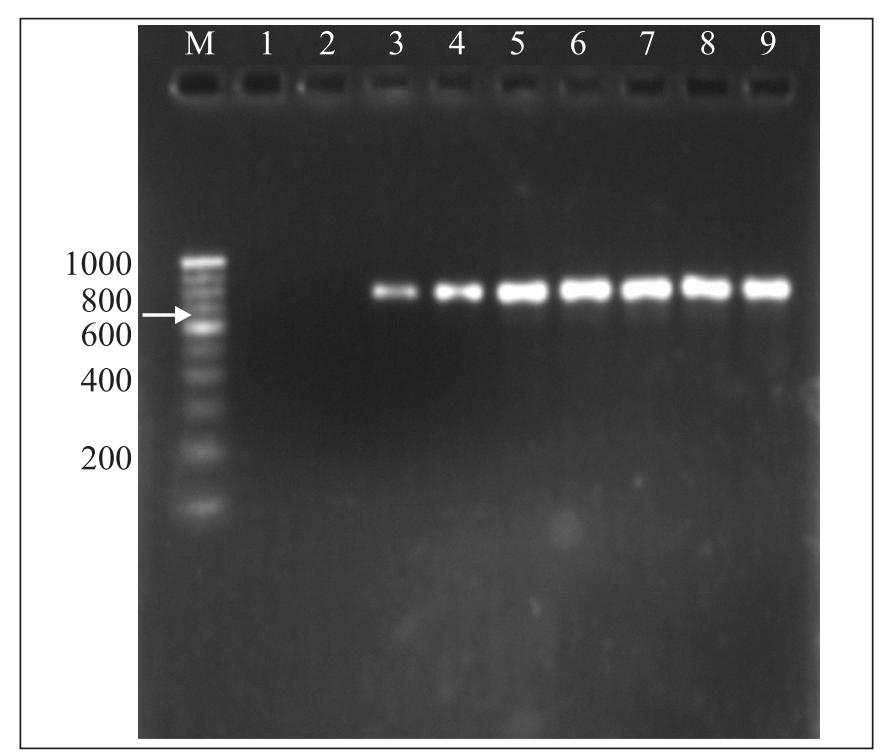

Figure 1. Agarose gel (1.5\%) showing 800bp amplified products of VERT-1 and VERT-2 regions of $F$. verticillioides DNA. Lane M: 1000 bp DNA marker; Lane 1: F. proliferatum; Lane 2: $A$. solani; Lane 3 - 9: F. verticillioides.
Table 1. Total number of Fusarium isolates tested and number of isolates positive for fumonisin production as analyzed by PCR.

\begin{tabular}{lccc}
\hline \multicolumn{1}{c}{$\begin{array}{c}\text { Fusarium } \\
\text { species }\end{array}$} & $\begin{array}{c}\text { No. of } \\
\text { Fusarium } \\
\text { isolates } \\
\text { tested }\end{array}$ & $\begin{array}{c}\text { No. of } \\
\text { Fusarium } \\
\text { isolates } \\
\text { positive } \\
\text { forVERT-1 } \\
\text { and VERT-2 }\end{array}$ & $\begin{array}{c}\text { No. of } \\
\text { Fusarium } \\
\text { isolates } \\
\text { positive } \\
\text { forVERTF-1 } \\
\text { and VERTF-2 } \\
\text { for set of }\end{array}$ \\
$\begin{array}{l}\text { F. verticillioides } \\
\text { F. proliferatum }\end{array}$ & 27 & primers & primers \\
F. anthophilum & 04 & 00 & 11 \\
F. graminearum & 04 & 00 & 00 \\
$\begin{array}{l}\text { Alternaria solani } \\
\text { (control) }\end{array}$ & 01 & 00 & 00 \\
\hline
\end{tabular}

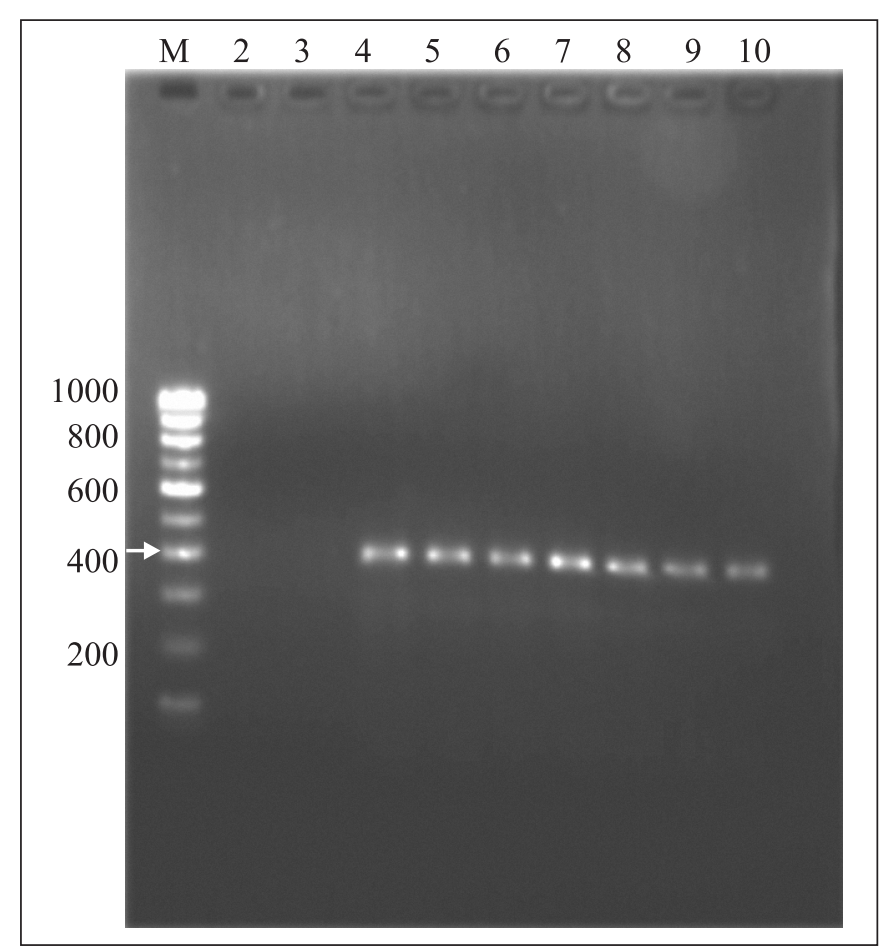

Figure 2. Agarose gel (1.5\%) showing 400bp amplified products of VERTF-1 and VERTF-2 fumonisin producing regions of $F$. verticillioides DNA. Lane M: 1000 bp DNA marker; Lane 2: F. anthophilum; Lane 3: F. graminearum; Lane 4 - 10: F. verticillioides. 
and protein dietary requirements (2). Therefore, studies on the incidence and prevention of mycotoxigenic fungi on paddy are very important. Systematic investigation on contaminating fungal species and their accurate identification is of paramount importance to take the appropriate preventive measures.

The PCR based method used in the present study was found to be quick and more sensitive in identification of $F$. verticillioides isolates, in comparison with agar plating method, which takes a minimum of 5-6 days. The PCR based method was also able to distinguish morphologically similar but toxigenically different $F$. verticillioides isolates.

The study revealed the prevalence of $F$. verticillioides in paddy and confirmed the association of fumonisin producing F. verticillioides isolates in paddy, collected from different regions of Karnataka state. The study, suggests the need for sensitive techniques for the quantitative analysis of fumonisins in paddy intended for human consumption. By such investigations it is possible to prevent the exposure of humans and animal life to toxic substances such as fumonisins.

\section{ACKNOWLEDGEMENT}

First author acknowledges to the University of Mysore for providing teacher fellowship under faculty improvement program (University order No. SPC/1/44/2005-06 dated: 03/05/2006).

\section{RESUMO}

\section{Detecção de Fusarium verticillioides produtor de fumonisina em arroz empregando Reação de Polimerase em Cadeia}

O estudo relata a ocorrência de Fusarium verticillioides produtor de fumonisina em 90 amostras de arroz armazenado, coletado de diferentes regiões geográficas de Karnataka, Índia. F. verticillioides produtor de fumonisina foi identificado baseado em características micromorfológicas e PCR empregando dois sets de primers. Um dos sets era $F$. verticillioides especieespecífico, que amplificava seletivamente a região do espaço intergênico do rDNA. O outro set de primers era especifico para $F$. verticillioides produtor de fumonisina. Oito amostras de arroz foram positivas para $F$. verticillioides. Onze isolados obtidos dessas amostras foram produtores de fumonisina.

Palavras-chave: Fusarium verticillioides, fumonisina, arroz, PCR

\section{REFERENCES}

1. Almeida, A.P.; Corrêa, B.; Mallozzi, M.A.B.; Sawazaki, E.; Soares, L.M.V. (2000). Mycoflora and aflatoxin/fumonisin production by fungal isolates from freshly harvested corn hybrids. Braz. J. Microbiol., 31, 321-326.
2. Anonymous. (2003). International year of rice 2004. Food and Agriculture Organization of United Nations (FAO), Rome. Italy.

3. Bankole, S.A.; Mabekoje, O.O. (2004). Occurrence of aflatoxins and fumonisins in pre-harvest maize from south-western Nigeria. Food Addit. Contamin., 21 (3), 251-255.

4. Bhalli, J.A.; Aurangazeb, M.; Ilyar, M.B. (2001). Chemical control of bakanae disease of rice caused by Fusarium verticillioides. J. Biol. Sci., 1 (6), 483-484.

5. Booth, C. (1977). Fusarium, Laboratory guide to the identification of major species. Commonwealth Mycological Institute. Ferry Lane. Kew, Surrey, England.

6. Bragulat, M.R.; Martinez, E.; Castella, G.; Cabanes, F.J. (2004). Selective efficacy of culture media recommended for isolation and enumeration of Fusarium species. J. Food Protect., 67, 207-211.

7. Silva, J.B.; Dilkin, P.; Fonseca, H.; Corrêa, B. (2004). Production of aflatoxins by Aspergillus flavus and of fumonisins by Fusarium species isolated from Brazilian sorghum. Braz. J. Microbiol., 35, 182-186.

8. Desjardins, A.E.; Manandhar, H.K.; Plattner, R.D.; Manandhar, G.G.; Poling, S.M.; Margos, C.M. (2000). Fusarium species from Nepalese rice and production of mycotoxin and gibberllic acid by selected species. Appl. Environ. Microbiol., 66 (3), 1020-1025.

9. Dilkin, P.; Mallmann, C.A.; Almeida, C.A.; Stefanon, E.B.; Fontana, F.Z.; Milbradt, E.L. (2002). Production of fumonisins by strains of Fusarium moniliforme according to temperature, growth period and moisture. Braz. J. Microbiol., 33, 111-118.

10. Domijan, A.; Maja, M.; Peraica, Z.; Jurjevic, E.; Ivic, D.; Cvjetkovic, B. (2005). Fumonisin B1, fumonisin B2, zearalenone and ochratoxin A contamination of maize in Croatia. Food Addit. Contamin., 22 (7), 677-680.

11. Edel, V.; Steinberg, C.; Gautheron, N.; Alabouvette, C. (2000). Ribosomal DNA-targeted oligonucleotide probe and PCR assay specific for Fusarium oxysporum. Mycol. Res., 104 (5), 518-526.

12. Fischer, P.J.; Petrini, O. (1992). Fungal saprobes and pathogens as endophytes of rice (Oryza sativa L.). New Phytol., 120, 137-143.

13. Ghiasian, S.A.; Bacheh, P.K.; Rezayat, S.M.; Maghsood, A.H.; Taherkhani, H. (2004). Mycoflora of Iranian maize harvested in the main production areas in 2000. Mycopathologia, 158, 113-121.

14. Jones, C.; Ciacci- Zanella, J.R.; Zhang, Y.; Henderson, G.; Dickman, M. (2001). Analysis of fumonisin B1-induced apoptosis. Environ. Health Perspect., 109 (2), 315-320.

15. Konietzny, U.; Greiner, R. (2003). The application of PCR in the detection of mycotoxigenic fungi in foods. Braz. J. Microbiol., 34, 283-300.

16. Leslie, J.F.; Summerell. B.A. (2006). The Fusarium laboratory manual. 1st edn., Blackwell Publishing. USA.

17. Makun, H.A.; Gbodi, T.A.; Akanyal, O.H.; Ezekiel, A.S.; Ogbadu, G.H. (2007). Fungi and some mycotoxins contaminating rice (Oryza sativa) in Nigeria State, Nigeria. African J. Biotechnol., 6 (2), 99108.

18. Mathur, S.B.; Kongsdal, O. (2003). Common laboratory seed health testing methods for detecting fungi. International Seed Testing Association (ISTA). Switzerland.

19. Nelson, P.E.; Dignani, M.C.; Anaissie, E.J. (1994). Taxonomy, biology and clinical aspects of Fusarium species. Clin. Microbiol. Rev., 7 (4), 479-504.

20. Pamphile, J.A.; Azevedo, J.L. (2002). Molecular characterization of endophytic strains of Fusarium verticillioides (=Fusarium moniliforme) from maize (Zea mays. L). World J. Microbiol. Biotechnol., 18, 391-396.

21. Park, J.W.; Choi, S.Y.; Hwang, H.J.; Kim, Y.B. (2005). Fungal mycoflora and mycotoxins in Korean polished rice destined for humans. Int. J. Food Microbiol., 103, 305-314.

22. Patino, B.; Mirete, S.; Gonzalez-Jaen, T.; Mule, G.; Vasquez, C. (2004). PCR detection assay for fumonisin producing Fusarium verticillioides strains. J. Food Protect., 67(6), 1278-1283. 
23. Rheeder, J.P.; Marasas, W.F.O.; Vismer, H.F. (2002). Production of fumonisin analogs by Fusarium species. Appl. Environ. Microbiol., 68 (5), 2101-2105.

24. Rosales, A.M.; Mew, T.W. (1997). Suppression of Fusarium moniliforme in rice by rice-associated antagonistic bacteria. Plant Dis., 81, 49-52.

25. Taligoola, H.K.; Ismail, M.A.; Chebon, S.K. (2004). Mycobiota associated with rice grains marketed in Uganda. J. Biol. Sci., 4(1), 271-278.

26. Taranu, I.; Marin, D.E.; Bouhet, S.; Pascale, F.; Bailly, J.; Miller, J.D.; Pinton, P.; Oswald, I.P. (2005). Mycotoxin fumonisin $B_{1}$ alters the cytokine profile and decreases the vaccinal antibody titer in pigs. Tox. Studies., 84, 301-307.

27. Trung, T.; Bailly, J.D.; Querin, A.; Le bras, P.; Guerre, P. (2001). Fungal contamination of rice from South Vietnam, mycotoxinogenesis of selected strains and residues in rice. Rev. Méd. Vét. Res., 152 (7), 555-560.

28. Zhang, Y.P.; Uyemoto.; Kirkpatrick, B.C. (1998). A small scale procedure for extracting nucleic acids from woody plants infected with various phytopathogens for PCR assay. J. Virol. Methods., 71, 45-50. 